\title{
Capitalist Reform, the Dismantling of the Iron Rice Bowl and Land Expropriation in China: A Theory of Primitive Accumulation and State Power
}

\author{
Larry Liu \\ University of Pennsylvania, Philadelphia, USA \\ Email: liam.ching.liu@hotmail.com
}

Received 29 September 2014; revised 10 November 2014; accepted 16 December 2014

Copyright (C) 2015 by author and Scientific Research Publishing Inc.

This work is licensed under the Creative Commons Attribution International License (CC BY). http://creativecommons.org/licenses/by/4.0/

\section{(c) (7) Open Access}

\begin{abstract}
Chinese economic reforms since 1980 were accompanied by the systematic privatization and devolution of state-owned enterprises, the removal of the social welfare system in the form of the "iron rice bowl", and the land expropriation of farmers. This paper uses Marx' theory of primitive accumulation and Weber's theory of state power to argue that these socio-economic measures are needed in order to create a class of wage laborers, who are needed to fuel capitalist development in contemporary China. The central, provincial, and local states in China are playing a crucial role in enforcing the privatization of state-owned enterprises, the removal of the social welfare system and land expropriation.
\end{abstract}

\section{Keywords}

Social Transformation in China, Welfare Policies in China, Marxian Theory, Weberian Theory

\section{Introduction}

Since 1980, enormous economic development has fundamentally transformed the Chinese economy and the society. In this time period, the Gross Domestic Product (GDP) per capita increased more than thirty times despite an increase in population (Nee \& Opper, 2012: p. 2). China’s GDP per capita had increased from \$469.2 in 1994 to $\$ 6188.2$ in 2012. ${ }^{1}$ The World Bank now designates China as an upper-middle-income country. This economic development has transformed the Chinese economy and by extension has a tangible impact on social indicators.

${ }^{1}$ World Bank. “GDP Per Capita (current U.S. \$)”. http://search.worldbank.org/data?qterm=gdp\%20per\%20capita\&language=EN

How to cite this paper: Liu, L. (2015). Capitalist Reform, the Dismantling of the Iron Rice Bowl and Land Expropriation in China: A Theory of Primitive Accumulation and State Power. Sociology Mind, 5, 41-60.

http://dx.doi.org/10.4236/sm.2015.51006 
Between 1981 and 2005, more than 630 million Chinese left their status of absolute poverty (income below \$1.25 per day), reducing that portion of the total population from $81.6 \%$ to $10.4 \%$ (Chen \& Ravillion, 2008). In addition, between 1994 and 2012, life expectancy increased from 70 to 75 years $^{2}$, showing that economic reform has benefited all income groups. Nonetheless, in that same time frame income inequality increased (ibid.: p. 3; Nee 1991; Yang, 1999). Sociologists and economists have carefully explored these tremendous economic changes (e.g. Lin, Cai, \& Li, 1996; Naughton, 2007; Brandt \& Rawski, 2008; Meyer, 2011), especially in context with state intervention (Oi, 1995; Walder, 1995; Frye \& Shleifer, 1997; Yang, 2004), private entrepreneurship (Huang, 2008; He, 2009; Nee \& Opper, 2012), institutional development (Hasan, Wachtel, \& Zhou, 2009; Yao \& Yueh, 2009; Cheng \& Degryse, 2010), the cheap labor supply (Zhang \& Yuk, 1998; Shi, 2001; Zhang, 2005), and the global political economy (Lardy, 2002; Breslin, 2007; Zweig \& Chen, 2007).

Economic transformations also involve deeply social processes, which require further exploration. Rapid economic development in China occurred at the same time as the hitherto peasant population left the countryside, and moved into the major metropolitan areas and cities in the quest for industrial jobs (Zhang \& Song, 2003), that arose from Western and Asian foreign direct investments (Graham \& Wada, 2003), a natural result of capitalist development. Rural-urban migration, which preceded urbanization, is, therefore, a key feature in contemporary Chinese society (Wu, 1994; Hare, 1999; Knight \& Song, 1999; Knight, Song, \& Huaibin, 1999; Zhao, 1999a; Seeborg, Jin, \& Zhu 2000; Song \& Zhang, 2002; Chang \& Brada, 2006). There has been an estimated annual flow of 50 - 60 million people from the rural areas to the cities, of whom 10 - 15 million settle permanently in the cities (Wu \& Zhou, 1996). The share of the total population that is urban has increased from $26.4 \%$ to $36.2 \%$ between 1990 and 2000 (Chan \& Hu, 2003). Rural to urban migration continues to increase even with the obstacle of the discriminatory household registration law, the hukou (Chan \& Zhang, 1999; Wong et al., 2007), and socialcultural discrimination of urban dwellers against the rural migrants (Zhao, 1999b). ${ }^{3}$ Much of this internal labor migration is confined to seven coastal provinces that absorb $82 \%$ of all migrant workers. ${ }^{4}$ This movement is accompanied by, on the one hand, material incentive structures, because rural areas are poorer than urban areas (Lu, 2012), because urban-rural inequality is increasing (Khan \& Riskin, 1998; Yang, 1999; Zhao, 2006), and because city life implied an improved standard of living. A migrant worker increases the household income on average by $8.5 \%$ to $13.1 \%$ compared to his old livelihood in the village (Du, Park, \& Wang, 2005). But, on the other hand, this migration is accompanied by the application of force by political authorities, who expropriate farmers from their territory (Guo, 2001), thus leaving farmers with no choice but to enter cities and urban areas.

The central problem confronting the researchers of China's rural-to-urban movement and the forceful dispossession of farmers is to find an explanatory framework to embed the large-scale, macro-structural economic changes that are happening in China into the social processes of change, especially with regard to the rural-urban migration and the expropriation of farmers. ${ }^{5}$ Specifically, why and how are farmers being dispossessed, and what are its relations to the path of Chinese capitalist development? The theorists Karl Marx and Max Weber have provided an analysis of the enormous transformations in the economic system within the context of social processes. In this paper, the author will use the Marxian theory of primitive accumulation, and the Weberian theory of state power in a macro-structural framework to explain the expropriation of rural farmers from their land, and the subsequent movement of people from the Chinese countryside to the city. By primitive accumulation, the author means the forceful seizing of land from farmers, which also compels these farmers to sell their labor in the factories in the city. By state power, the author means the use of formal government authority and bureaucracy to enforce the outcome of primitive accumulation. The explanatory framework is macro-structural, because the units of analysis are the Chinese authorities, the farmers as a class, and the dynamic of the capitalist system working in China. This paper will proceed with a descriptive account of Marx and Weber's theories on primitive accumulation and state power, followed by an application of those theories to capitalist reform, the privatization of state-industries, the destruction of the "iron rice bowl", and land expropriation in China. The key hypothesis is that primitive accumulation using the state as a guiding mechanism is an important process in Chinese capitalist development. It is by separating the Chinese farmers from their land and welfare provisions that factories in the cities can be filled, and propel capitalist development.

\footnotetext{
${ }^{2}$ World Bank. "Life expectancy at birth, total (years)." http://search.worldbank.org/data?qterm=life+expectancy\&language=EN\&format= ${ }^{3}$ The hukou assigns privileges and benefits, such as school enrollment or access to health care, based on the geographic origin of the persons, which poses a direct discrimination against migrant workers and their families due to their restricted access to those goods and services. It was originally designed to restrict migration.

${ }^{4}$ Sam Stearman. China’s Migrant Workforce—A Special Report. http://www.samsays.com/SIP-CBA1.htm

${ }^{5}$ The problem of social-economic embeddedness is taken up by Granovetter (1985) and Polanyi (1944).
} 


\section{Primitive Accumulation and State Power}

\subsection{Marx}

In Marx' writings, one of his objective was to describe the dynamic process that is involved in capitalism, and how profoundly it alters the nature of society (e.g. Marx, 1846, 1848, 1850, 1852, 1867, 1871, 1875, 1885, 1894; Tucker, 1978). In his writings he tried to show that the capitalist system is afflicted with so many contradictions that it has to break down and be replaced by a socialist system. Marx is described as a "narrowly focused... political crusader", whose "intellectual life was channeled into an almost monomanical obsession with building a system of political economy that would undergird his vision of the Communist future” (Collins, 1994: p. 59). He had also been called a "prophet" (Schumpeter, 1942) due to his great appeal as a social theorist, who could tie social and economic phenomena together, using a conflict-historical approach (Collins, 1994: p. 49). Marx’ writings had inspired a host of followers, some of whom may be considered Marxists (e.g. Engels, 1884; Hilferding, 1910; Luxemburg, 1913; Lenin, 1917; Sweezy, 1942; Wallerstein, 1974, 1980, 1989, 2011; Harvey, 2003, 2005, 2010; Derleugian, 2013). ${ }^{6}$

Marx' theory of primitive accumulation delineates a crucial process in the capitalist economy. Marx' question was what the necessary social circumstances for capitalism were. Successful capitalist development required the creation of a labor force that is willing to work in capitalist enterprises, especially in factories of the major cities. Only wage labor can add surplus value, i.e. the value produced by the worker exceeding the cost of employing the worker, to the capitalist, which forms the basis of profits. But self-sufficient farmers are very unlikely to be interested in working in filthy factories, which may be connected with increased conveniences and a higher living standard at some indeterminate future point, but immediately implied terrible working conditions, as is implied in the many British factory reports that Marx cited in his work (especially Marx, 1867: Chapter 15). It is also very unlikely to assume that the farmers will appreciate the lure of capitalism, and will prefer to stick with their old ways. But if there are no workers, then the capitalist is in trouble.

The social basis of capitalism is a workforce that is available for exploitation in the Marxian sense (i.e. with reference to the production of surplus value). It is like Erik Olin Wright (1997: pp. 4-7) described in his comic on the parable of the shmoo. In this short comic, two capitalists go into a poor neighborhood and attempt to enlist the people from that neighborhood to work in their can factory. But as the capitalists arrive, they realize that the people in the community had animals called "shmoo", who produced all the life's necessities for the people for free. The shmoo, in this comic, were the means of production that were owned in common by the community. There was, therefore, no incentive for the people in that community to join wage labor to secure themselves the goods and services necessary for life.

Marx reasoned that in order for a capitalist system to succeed the independent farmers had to be eliminated, which forms the basis for creating free labor, which is free in the double sense: it is formally free to sell its labor power, and it is also free of (or without) ownership over the means of production, and therefore left without choice but to sell its labor (Marx, 1867: Chapter 6). This separation between the mass of people from the possession of their own means of production can be achieved by using government power to expropriate the farmers from their land (Marx, 1867: Chapter 26). ${ }^{7}$ This is what happened to the farmers in Britain. Marx had observed that with the dissolution of the bands of feudal retainers in the late fifteenth and early sixteenth century. During the Reformation, the Catholic Church as feudal proprietor of soil in England saw its monasteries dissolved, which hurled many monks into the proletariat. By the mid-eighteenth century the yeomanry, the independent farmers, largely disappeared. When the Stuarts came to power the landed proprietors used legal methods to usurp property into their own hands, with the help of the abolition of feudal tenure of land. During the Glorious Revolution, landed capitalists seized state lands by converting it into private property. Notice that the capitalist relied on state power to get what he wanted. This concept will be further theorized below in my use of Weberian theory.

The nascent capitalists could accomplish two objectives at once: public and church estate has become commercial private property, which allowed the accumulation of capital in the hands of those capitalists. As peasants were forcibly removed from their land, a helpless proletariat was created, some of which became paupers, and others became wage laborers on behalf of the capitalists (Marx, 1867: Chapter 27). The victors in this class

\footnotetext{
${ }^{6} \mathrm{~A}$ more complete listing of Marxist literature can be found on my blog (Liu, 2013a).

${ }^{7}$ In many cases, it was technically not the land of the farmers, but of the feudal landlords. Even though that social relationship was also inherently exploitative, there was no pretension about the exploitation. In the corvee system, the peasants would work three days of the week for their own subsistence, and three days of the week for the landlord, who granted military protection to the tenant farmer in return.
} 
struggle was the landed upper class (which was really capitalist), and the losers were ordinary peasants (Moore, 1967: p. 11). The land expropriation meant "that the curtain which separated the growing army of labourers from utter proletarianization was torn down” (Chambers, 1953: p. 336). In Marx’ own words, “The spoliation of the Church's property, the fraudulent alienation of the state domains, the theft of the common lands, the usurpation of feudal and clan property under circumstances of ruthless terrorism, all these things were just so many idyllic methods of primitive accumulation. They conquered the field for capitalist agriculture, incorporated the soil into capital, and created for the urban industries the necessary supplies of free and rightless proletarians” (Marx, 1867: Chapter 27). ${ }^{8}$

The most interesting contrast is provided by the American colonies from the beginning of European colonization until the nineteenth century. In the colonies, Marx noticed that the capitalists had enormous difficulties to penetrate these territories, even as the economy was developing fabulously and the economic resources were abundant to carry out capitalist development. The problem for the capitalist was that unlike in Europe the American capitalist at the beginning could not easily enlist loyal workers into their enterprises, because the individual workers can freely accumulate resources for themselves. Because the land was so abundant, the new immigrants from Europe could work for a few years with their capitalist employer, but could later easily decide to move out West to occupy unused land. The enormous amount of land and natural resources without sufficient labor to handle it produced an enormous labor shortage, and a rise in wages that, in some cases, was even hurtful to capitalist profits (Marx, 1867: Chapter 33). Marx cited the British politician Edward Gibbon Wakefield, who noted of the colonies that " $[\mathrm{w}]$ here land is very cheap and all men are free, where every one who so pleases can easily obtain a piece of land for himself, not only is labour very dear, as respected the labourer's share of the produce, but the difficulty is to obtain combined labour at any price” (Wakefield, 1833: p. 247). The example of the colonies shows that certain socio-political conditions, where wage labor is abundant, are necessary for the successful creation of capitalism, and that these conditions are least likely to emerge in relatively free societies that grant more real, practical economic freedoms to the mass of the population.

The use of the term "primitive accumulation" implies that this original process of capitalists stealing private property from small independent farmers using the help of state power is an obsolete and old process, which is not relevant anymore to the contemporary period. But scholars like David Harvey (2003: p. 144) argue that primitive accumulation is not out-dated, i.e. primitive, at all, but can still be observed today. He, therefore, preferred to call primitive accumulation "accumulation by dispossession" instead due to the timelessness of its meaning. Examples are the displacement of farmers in Mexico and India, who became landless proletariats (ibid.: p. 145). The privatization of hitherto common water resources and other state functions, the suppression of alternative, non-capitalist (petty) forms of production, the replacement of family farms with agri-business, the continuation of slavery in the form of the sex trade, different forms of financialization (i.e. stock promotion and manipulation, ponzi schemes, corporate fraud, raiding of pension funds, asset-stripping in mergers and acquisition, debt promotion among the population etc.) are named as further examples of such accumulation by dispossession (ibid.: pp. 145-147). The increase in public debt, accompanied by rising unemployment, increasing inequality, growing tax resistance and declining political participation leading into welfare state retrenchment and the privatization of state functions (Streeck, 2013) may similarly be regarded as a contemporary form of accumulation by dispossession. ${ }^{9}$ There are many possibilities for finding examples of primitive accumulation, using Harvey's very expansive definition. Indeed, for the purposes of my own analysis of contemporary China, the author will also employ Harvey's more expansive definition of primitive accumulation to analyze the capitalist reforms, the retrenchment of the communist social welfare system, and land expropriation.

\subsection{Weber}

Max Weber's (1946, 1948, 1978, 1981) writings were similarly concerned with how the rapid economic transformation, that he was living through, affected the society, falling well in line with the historically oriented conflict tradition in sociology (Collins, 1994: p. 81). In fact, his magnum opus was titled Economy and Society (Wirtschaft und Gesellschaft), where he applied his wide-ranging world-historical theories about bureaucracy,

\footnotetext{
${ }^{8}$ The enclosure of land in Britain and its peculiar welfare policy (Speenhamland Law) is superbly described in Polanyi (1944). The class struggle of seventeenth century England is described by the social historian Christopher Hill (1972). Barrington Moore (1967: pp. 3-39) theorized about enclosure having benefited the landed upper class.

${ }^{9}$ There has been a lot of work on contemporary neoliberalism and the power of finance, e.g. Campbell and Pedersen (2001); Duménil and Lévy (2001, 2009, 2011); Epstein (2005); Harvey (2005); Krippner (2005); Stockhammer (2010).
} 
rationalization, religion and capitalism, class/status/power, charisma, life chances etc. Weber is described as "the greatest German sociologist” (Collins, 1994: p. 44). ${ }^{10}$ Weber himself produced a lot of followers, who took up his concerns about the economy and society to develop their analyses (e.g. Parsons, 1937; Mannheim, 1940; Mills, 1956; Dahrendorf, 1959; Lenski, 1966; Collins, 1975, 1986; Habermas, 1975; Mann, 1986, 1993, 2012a, $2012 b)$.

Weber made many very similar observations as Marx. One could in a simplifying way claim that he was Marx, but without a revolution and somewhat more liberal admiration for capitalism, even though this claim may be disputed by some scholars (Bittman, 1986). ${ }^{11}$ Weber analyzed that free labor is an important part for the successful development of capitalism. Free labor has to operate "under the compulsion of the whip of hunger" in order to allow a clear calculation of the costs of products in the market place (Weber, 1981: p. 209; Collins, 1980: p. 928). The creation of free labor, therefore, implies that the mass of people, mainly peasants, become willing to voluntarily move out of their old livelihood, and join the urban factories as wage laborers. It implies, on the other hand, that someone has to apply force against the peasants in order to secure the transition into the proletariat. Weber argued that the expropriation of independent producers was a crucial process for the development of capitalism, which is comparable to the development of the modern state, which expropriated executive power from private rulers (Weber, 1946: p. 82). One example are the local warlords of the 1910s and 1920s in China, which were soundly defeated by Chiang Kai-shek's nationalist army (Taylor, 2009: pp. 49-96). In the analysis of the state, whose modern form correlates very strongly with the development of capitalism, Weber also noted that its rise required the separation of the administrative staff from the administrative officials ${ }^{12}$, and the workers from the material means of administrative organization (Weber, 1946: p. 82).

Weber also noted that the establishment of private property which is enforced by the government in the form of laws (e.g. commercial register, elimination of dependence of an association and the firm, separate property of the private firm or limited partnership, and laws on bankruptcy) is an important characteristic in the rise of capitalism (Weber, 1978: pp. 378-380). Again, we see a parallel analysis between the state and the private-sector economy. Weber emphasized the institutional basis of capitalism, but was more specific about that than Marx. Marx noted at times the role of the state in enforcing private property rights, but he seemed to be more inclined to take it for granted $^{13}$, as did many of the classical political economists, from whom Marx built his own political economy. In his early writings, Marx (1848) did argue that "the executive of the modern state is but a committee for managing the common affairs of the whole bourgeoisie”. Though on a grand scale this may be correct, it is much too imprecise, and here the trained legal historian Max Weber suggests a more viable political sociology with which to analyze state power with respect to the primitive accumulation process.

Weber's theory of state power is formulated in clear sociological terms. Building on the quote by Trotzky that “every state is founded on force”, Weber (1946: p. 78) defined the state as a "human community that (successfully) claimed the monopoly of the legitimate use of physical force within a given territory". The state is also the ground, where political maneuvering by individuals and groups of people occur, and is, therefore, not an abstract, extraneous entity as is perceived in American popular discourse. Weber continues to argue that "politics" needs to be defined as the "striving to share power or striving to influence the distribution of power, either among states or among groups within states” (ibid.: p. 78). State power, which is wielded by politicians and other influential political leaders ${ }^{14}$, is not an arbitrary force of violence, but a legitimate source of violence. This is a matter of definition. If the state would not have enough power or legitimacy to inflict violence against the populace or a part of it, then there can't be a state, and it must be an anarchy, as Hobbes (1969) had formulated it. State legitimacy may

\footnotetext{
${ }^{10}$ In this case, I will disagree with Collins, who is unduly neglecting Marx as one of the two great German sociologists. It is these two plus Durkheim, who are considered the key sociologists. Collins (1994: pp. 56-62) essentially argues that Marx' companion Friedrich Engels was the great sociologist, who convinced his friend Karl to pay more attention to historical and economic sociological concerns. It was when Marx read Engels' Condition of the Working Class in England (1845) that Marx' focus became more practical and sociological and less philosophical. That is very much right, but the relevance of Marxism for contemporary sociologists and other social scientists reveal to me at least an equal consideration of both Marx and Weber as the best German sociologists.

${ }^{11}$ A more rigorous comparison between Marx and Weber can be gleaned from Birnbaum (1953). Anthony Giddens (1970) argues that Weber had really been influenced not so much by Marx, but by Marxists, who were politically influential in early twentieth century Germany (e.g. Social Democratic party, Communist party), and could, therefore, not be ignored in German social science discourse.

${ }^{12}$ Weber's theory of bureaucracy is extensively discussed in his Economy and Society (1978: pp. 956-1003).

${ }^{13}$ Though to be fair: Marx' treatment of primitive accumulation and enclosures in Britain did put the state front and center, so the distinctions between Marx and Weber are more a matter of emphasis rather than substance. On the other hand, Marx treatment of the state is only limited to these examples. Marx main theoretical concern was located in the political economy, i.e. the accumulation and circulation of capital, the production of surplus value, and economic crises etc. The state is largely subservient to those economic-structural processes.

${ }^{14}$ The best sociological studies about leaders and elites were carried out by Mills (1956), Useem (1979), Domhoff (1990), and Bourdieu (1998).
} 
be gained by traditions (habitual orientation to conform to the patriarch or the patrimonial prince); charisma (extraordinary and personal gift of grace of the power holder), and legality (belief in the validity of legal statutes and functional, rational rules) (Weber, 1946: pp. 78-79). It should be noted that Weber conceded that these three forms of state legitimation are only ideal-types, and a variety of motives (e.g. fear of punishment and hope for reward) may induce subjects to become obedient to the state and its leading officials (ibid.: p. 79). How power eventually is distributed across society has to be analyzed within the context of class, status and party (Weber, 1978: pp. 926-939).

One more application of Weber's treatment of the state as a locus of power was his discussion of capitalist imperialism, which is considered the "direct exploitation of political political power directed towards expansion", which serves the economic interests of tax-farmers, state creditors (banks, companies, investors etc.), suppliers of the state, overseas traders and colonial capitalists (ibid.: p. 917). Imperial capitalism is the strongest, where the state plays an important role in the economy, securing profit and growth opportunities (ibid.: p. 918; Collins, 1986: p. 150). The analogy of internationally oriented imperialist capitalism may be applied to national conditions as well. Here the nation-state has full legal and political access to use coercive mechanisms to secure continued capital accumulation for capitalists without the legal insecurity of Hobbesian anarchy in the global arena. And such coercive mechanism includes, among others, the primitive accumulation from farmers in China.

Though the Weberian theory of the state is general true across most historical time periods (making it somewhat ahistorical, yet theoretically enduring), he recognized that historically state formation involved this conflict between different nationally-based groups (whether on linguistic, cultural, ethnic or political grounds), so that internal unity, the formation of an army, and the raising of taxes to maintain it, are essential to fend off the foreign enemy (Weber, 1946: p. LXXXIV). This may also explain why countries tend to have internal warfare, when they are at peace with other countries. ${ }^{15}$ If the state cannot maintain internal unity when it matters, such as during state fiscal crises, then the state may break down and a social revolution may occur (Skocpol, 1979; Goldstone, 1991). China’s current Communist party leadership may not be immediately concerned about a social revolution, but they are concerned about what greater protests against their regime might imply for its own political future. Weber's theory of state power is salient in the case of primitive accumulation in China, because it is the provincial and local governments, i.e. the agents of monopolized violence, which carry out the privatization of firms and social services and the expropriation of farmers.

Even though I characterize the primitive accumulation theory as Marxian, and the state power theory as Weberian, it is quite clear that Marx as well as Weber acknowledged the theoretical contributions of the other (though historically Weber comes after Marx). Marx and Weber both acknowledged the importance of state power in enforcing primitive accumulation, which is the social and economic pre-requisite to the successful development of a capitalist economy. This major theoretical contribution shall now be applied to contemporary social and economic processes in China.

\section{Social Processes in Contemporary China: Capitalist Reform, the Dismantling of the Iron Rice Bowl and the Expropriation of Farmers}

In the following section, the author will apply the theories of primitive accumulation and state power to the case of land expropriation in rural China, but will first delineate briefly the initial condition of farmers during communism in China and the "Iron Rice Bowl" in order to set the current policies into its appropriate economic-historical context.

\subsection{Capitalist Reforms in China}

Since 1978, Deng Xiaoping’s policy of economic reform (also referred to as 改革开放, gaigekaifang) took hold. Previously, China really had run a Soviet-style command economy (Ward, 1980; Naughton, 1995: p. 26). One of the first reform measures was to achieve agricultural mechanization, which was accompanied by the development

\footnotetext{
${ }^{15}$ Political unity may have some troublesome implications too with regard to the quest for international dominance. Interestingly, the geographer Jared Diamond (1997) argues that Europe became the first imperial power, and not China due to geographic reasons. Europe due to its balkanization based on natural barriers like rivers, mountains, coast lines and multiple islands and peninsulas, created linguistically and culturally different states and political entities that in constant competition with each other refined military and industrial technology, which helped in their ascendancy, while the Chinese enjoyed strong political unity thanks to their vast landmass, which allowed easy central political control, but also made the Chinese more isolationist and shun innovation and trade from abroad, at very dear cost to them as $19^{\text {th }}$ and early $20^{\text {th }}$ century history revealed to them.
} 
of heavy industry (Naughton, 1995: p. 67). Chemically-based industries were developed to substitute for scarce agricultural land, meaning that the massive development of fertilizers increased the output from existing land. At the same time large-scale chemical fibre production substituted for natural fibres, to free up more land for food production (ibid.: p. 68). Mechanization and more heavy industry, however, required more availability of petroleum, which was not as forthcoming to the planners as desired (ibid.: p. 73).

Subsequently, the leaders shifted their industrial strategy by allocating industrial output away from energy-intensive investment good production toward labor-intensive and energy-frugal consumption. This allowed China to advance industrialization without immediately requiring a massive increase in energy consumption, as energy was lacking (ibid.: p. 77). This observation matters in context with the greater need for cheap laborers, which had to be drawn from the countryside. With the combined processes of increased agricultural productivity thanks to farm reforms, and a baby boom in the 1950s, enormous surplus labor developed in the rural areas in the mid- 1980s (Liu, Li, \& Zhang, 2003; Rush, 2011). The ensuing employment crisis was tackled by the enormous expansion of labor-intensive light-manufacturing and service jobs in urban areas (Naughton, 1995: p. 77). And the labor was clearly available for it. The key was to raise agricultural output, which would also allow for a rapid expansion in the consumer goods industry, which would absorb excess labor in both the city and the countryside, allowing also a general rise in the standard of living (ibid.: p. 78). Millions of urban youth that had been sent into the countryside during the Mao-era Cultural Revolution in the 1960s were sent back to the cities (ibid.: pp. 89-90). Migrant laborers from the countryside were increasingly pulled into the successful coastal regions, so that in 2012 there were about 30 million migrant laborers in the province Guangdong alone (Chan \& Siu, 2012: pp. 82-83).

China's economic transformation also implied a reduction of the state sector. Deng Xiaoping's proverb was "to let some people get rich first". Household income as percentage of disposable income increased from $55 \%$ in the pre-reform period to $70 \%$ in 1983-84, while the state revenues as a portion of GNP declined from $35 \%$ in 1978 to 27\% in 1982 (Naughton, 1995: pp. 82-83). Unprofitable enterprises, which had been propped up by inefficient state subsidies, were shut down as overall subsidies declined (ibid.: p. 84). State expenditures on the military and on investments also declined (ibid.: p. 85). Government revenues as share of GDP reached a low point in 1995 (10.7\%), but has been on the increase ever since, reaching $22.7 \%$ in $2011 .{ }^{16}$ Chinese policy-makers also advanced privatization by reducing and abolishing state monopolies, relaxing restrictions on private-sector activities, and allowing the entry of private firms (Yip, 2006: p. 51). In agriculture this meant that villages, while still owning the land, contracted that land to peasant households for farming purposes.

After 1984, so-called commune and brigade enterprises, operating relatively independently from central state control, organized in "township village enterprises", and began to process rural raw material and supply consumer goods to the cities (ibid.: p. 53). The self-employed individual economy, called "getihu", became legal (ibid.: p. 54), and increased from about 160,000 in 1978 to over 7 million in 1984 (Kraus, 1991: p. 64). State-owned enterprises in the city were subjected to greater market forces, because the authority of the party secretary was curtailed, while the role of the business manager, who cared only about enterprise performance and the delivery of profits, was strengthened (Yip, 2006: p. 55). The pace of privatization reform slowed down somewhat in the 1989-91 period, due to conservative opposition in the Communist Party, and anti-bourgeois ideology during the Tiananmen protests of 1989 (ibid.: p. 56), which the government brutally crushed. But that was only a short intermezzo, because from 1993 onward, the government allowed state-owned enterprises (SOE) as independent legal identity, i.e. corporation. This also implied a full-scale separation between the SOEs and the government, forcing the SOEs to operate independently in the market (ibid.: p. 57). Since the 2000s, private capital has entered industries that the government deemed an essential public good, such as banking, aviation and oil (ibid.: p. 59). Though the state still invests in companies, it rarely establishes purely state-owned companies, but seeks mixed ownership with private capital and shareholders, and private management (ibid.: p. 60).

From a theoretical standpoint, the increase in agricultural productivity is the basis for an increase in wealth and also for the kick-starting of capitalist economic development, as more resources can be shifted to the production of industrial and manufacturing goods, which is actually a process going back as far as the Mao Zedong era of the 1950s, though at enormous social cost (The Great Leap Forward is described in detail by Teiwes and Sun, 1999). But it really took off in the 1980s, with Deng Xiaoping's reform effort. The social impact of an increase in agricultural productivity is the dismantling of the old, predictable, agricultural lifestyle of the farmers. The temporary disorientation of the farmers is usually resolved by migration to the city on the eastern seaboard, where the

\footnotetext{
${ }^{16}$ International Monetary Fund. “China: Government Revenue, Percent of GDP.” Quandl.com.

http://www.quandl.com/IMF-International-Monetary-Fund/GGR_NGDP_924-China-General-government-revenue-Percent-of-GDP
} 
investments and jobs are. Though this process of greater agricultural productivity cannot be considered primitive accumulation, which implies the application of some kind of force, preferably by the state, it sets the stage for it. The reduction of the state sector in the form of privatization, however, may safely be regarded as a form of primitive accumulation, because the workers' livelihood is taken away from them, which hitherto had been guaranteed to them. The reduction in social services or the destruction of the "iron rice bowl" will be discussed in the next section.

\subsection{The Dismantling of the Iron Rice Bowl}

Privatization also involved a reduction in the public delivery of social services in the form of the "iron rice bowl". Removing and weakening this social safety net is an important element of primitive accumulation, and is, therefore, part of promoting capitalist development. This privatization, ironically, was termed "socialization of social welfare", which meant the devolution of responsibility of social welfare from the central government to the local communities, mass organizations, enterprises, families and individuals (Yip, 2006: p. 72; Wong, 2001). In the early 1980s, the Chinese state essentially privatized and dismantled the public delivery of health care. From 1978 to 1999 , health care expenditures from the state decreased from $32 \%$ to $15 \%$, which had the impact of increasing urban-rural disparities in health care access, because most of the support went to the wealthier coastal regions, where patients could afford better health care. The disappearance of rural, low-cost barefoot doctors implied a deterioration in rural access to health care. It is only since 2002 that the government started to roll out more state involvement in the provision of health care to the population (Blumenthal \& Hsiao, 2005). At least somewhat of a Polanyi-style “double movement” has surfaced (Polanyi, 1944). As I would argue, the enormous burden on private household budgets in the provision of hitherto publicly-provided health care, especially among poor people in China, creates an economic pressure to join wage labor, preferably in the major cities where the jobs and investments are located in. The reduction in the role of the state, more importantly, also involved the smashing of the “iron rice bowl” (Leung, 1994; Hughes, 1998; Ding, Goodall, \& Warner, 2000; Fung, 2001).

Under the old "iron rice bowl” the SOEs provided a comprehensive, cradle-to-grave welfare system to their employees. Social security provisions included benefits for sickness, maternity, work injury, invalidity, death and old age pensions. In addition, there were allowances for rent, food, transportation, bathing, haircuts, fuel, single child benefits, sanitation and visit to family members. Collective welfare services also included nurseries, kindergarten, staff quarters, primary and secondary schools, clinics, hospitals, recreational club houses, libraries, cinemas, and canteens. These welfare provisions were often financed directly by the state, as many SOEs were chronically uneconomical (Leung, 1994: p. 343). Welfare benefits were handed out indiscriminately, even though they were low (Walder, 1989: p. 243). Workers were also guaranteed a job, and did not have to look for one (Fung, 2001: p. 259). The smashing of the "iron rice bowl" really goes in tandem with the privatization wave, because since 1984 after the third Central Committee, efficiency in firms was elevated as the highest goal, and company managers were now permitted to lay off workers (ibid.: p. 268). With the passage of the Enterprise Ordinance in 1991, the companies were given full power to determine the precise conditions, methods, quantity and period of time that they wanted to utilize labor (ibid.: p. 269).

A withdrawal of state support, privatization and marketization implied job losses and the creation of unemployment among many workers and social unrest. Downsizing in the SOEs accelerated in the late 1990s. As managers have been exposed to market discipline, they were forced and encouraged to cut costs using downsizing as a legitimate mechanism (Yip, 2006: p. 71). The number of laid-off SOE workers increased from 3.7 million to 6.2 million in 1999 (Giles et al., 2005: p. 150). An estimated one-third of SOE workers were considered redundant (Ma, Fok, \& Ko, 1997). The official urban unemployment rate increased from 2.3\% in 1991-2 to more than $4 \%$ in the early 2000s (Yip, 2006: p. 71), though some people estimate that rate to be much higher (Xue \& Zhong, 2003; Giles et al., 2005). The government subsequently tried its best to improve the legitimacy of private-sector companies hoping that they would increase their hiring of labor, but in the early-2000s, domestic private companies accounted for only one third of the new jobs for workers that had lost them during the downsizing process (Yip, 2006: p. 72). In 1993, the government set up an unemployment insurance scheme (another Polanyi "double movement"), though it was narrowly confined to SOEs, and the contributions and benefits were low, covering only $40 \%$ of the worker's wage. Besides, in the mid-1990s, many unemployed workers were sent back to their state-owned enterprises (“enterprises of origin”), where alternative forms of employment were sought for these workers (Fung, 2001: p. 269). The "iron rice bowl” had been substantially dismantled, though not completely, perhaps due to fears about rising labor tensions. In the words of Deng Xiaoping, who urged the country to pursue 
"common prosperity”, “Things would be quite different when indulging in polarization, as that would give rise to national conflicts, regional conflicts and class conflicts and correspondingly the conflicts between the center and localities, which would lead to disturbances” (quoted in Hu, 2007: p. 226).

Harvey (2003) and I (and Marx (1867) and even Weber (1981) by extension) would consider this dismantling of the iron rice bowl to be the crucial mechanism of primitive accumulation, in which wage labor is "freed” up (i.e. created) for industrial use. And as Weber would remark, the state that exercises the monopoly of violence, is playing a crucial role in that process. The combined processes of implementation of market mechanisms, the privatization of hitherto public resources, the rise in urban-rural wealth and income disparities, the collapse of the "iron rice bowl" all produce the pressures for rural-to-urban migration, and that occurs even without the technical requirement for the land expropriation of rural farmers! This does not necessarily contradict my hypothesis about the necessity of land expropriation for capitalist development, but supplements it. Emphasizing the institutional framework, in which the dispossession of farmers is occurring, the particular Chinese developmental path eventually encourages (if not require) the expropriation of farmers at some point. This developmental path involves the creation of a capitalist economic system with its conscious promulgation of uneven development favoring the densely populated cities on the coast first, while only gradually absorbing the countryside in terms of labor, land and resources. But absorbing the countryside is a must, because given the right institutional framework, such as laws and norms by the state (cf. Weber's (1978: Chapter 8) sociology of laws), capital has to expand to regions with lower incomes and lower levels of development in order to grow. Pre-capitalist arrangements like the "iron rice bowl” or small, subsistence-level farmers are really an obstacle to capitalist development. Similarly, the farmers' attachment to their land was also another barrier to capitalist development, which is discussed in the next section.

\subsection{Land Expropriation in Rural China}

Land expropriation of farmers by the local Chinese government is another important element of primitive accumulation, whereby farmers are separated from their land, often by force and only with some compensation, forcing these farmers to seek paid labor in the cities. This process can be divided into three phases: one in the early-1980s, a second wave around 1992 and a third since 2003. The structural force behind expropriation is urban sprawl, which invades into farmland (He et al., 2009: p. 1926). It is often undertaken by local political leaders eager to convert farmland into industrial and residential property, and these leaders benefit from it in the process (Lichtenberg \& Ding, 2008). ${ }^{17}$ The state at all levels is the owner of land and natural resources (He et al., 2009: p. 1930). Generally, the Chinese land use rights give local governments the ability to access untapped revenues, which provides the motivation for them to advance land expropriation, even though some constraints are imposed on it through the land quota system. However, local governments circumvent the quota system by collaborating with other local governments in order to transfer quotas from regions with land abundance to those with land scarcity, allowing the land abundant areas to expand land expropriation (Cai, 2012). Land-related revenue accounts for up to $60 \%$ of total fiscal income for many local governments (Ding, 2007). The local cadres, officials and developers usually agree on informal deals to convert collective land into urban construction land without asking the farmers for their opinion about that decision (He et al., 2009: p. 1931). An upper class, consisting of private developers, is the prime beneficiary of the expropriation, as they receive land for their property developments, while most farmers are the losers, who are pushed into poverty. "There is a very real sense in which the modernization and affluence of Chinese cities are achieved through sacrificing farmers' interests” (ibid.: p. 1926).

To view it in terms of the sociology of power, the state and its officials have the most power, because they own the land (i.e. means of production), then come the buyers/developers, who obtain de-facto control by the purchase of the land, and the least powerful are the farmers and the village households, because they do not control the land (ibid.: p. 1933), and have to content themselves with compensation by the government, which they also do not determine. Compensation for land is stipulated to be 6 - 10 times the average annual land productivity, and resettlement subsidies are supposed to be 4 - 6 times it, though in exceptional circumstances that value may be higher (ibid.: p. 1934). But that is not really helpful to dispossessed farmers, who struggle to gain employment or receive entitlement to social security (ibid.: p. 1935). A survey by the China Statistical Bureau in 2003 found that

\footnotetext{
${ }^{17}$ Corruption among Chinese officials is becoming an increasing problem, especially in the Chinese form of capitalism that is so state-reliant for its development (e.g. Lu, 2000; Yan, 2004). Imperial China during the Qing dynasty (1644-1911) had a class of well-educated bureaucrats (Weber called them 'literati'), who taxed commerce and milked the land for their own benefit (Moore, 1967: p. 175). Interestingly, this bureaucratic class had hitherto been a great obstacle to capitalism (Weber, 1978: p. 201).
} 
$56 \%$ of the surveyed landless farmers from 28 provinces had experienced a significant decrease in income. Only $38 \%$ of those surveyed in Shaanxi province were able to find a job (Rural Investigation Team, 2003). This expropriation often leads to land disputes, and it accounts for $65 \%$ of all cases of social unrest in China. Much of the expropriation takes place in areas that are close to urban areas (Gobel \& Ong, 2012: p. 37).

Farmers are-with some exceptions_-politically unorganized, and cannot institutionally resist land expropriations (Cai, 2003). Even though social protests by peasants had been on the increase, so has the crackdown by local governments, who can otherwise not quell popular anger by modest concessions (Cai, 2008). Governments doing the expropriation are supposed to compensate the farmers for their action, but the size of compensation is usually very small relative to the economic damage inflicted on the farmers (Liu \& Lou, 2004). Though in Xiamen, Fujian province, the local government did grant some more concessions to farmers, including compensation for lost land, and also a share of proceeds from the urban land value uplift, resulting from local infrastructure projects (Zhao \& Webster, 2011).

The expropriation and dislocation of Chinese farmers has also led to the creation of what is called a "floating population", which involves people who move into another part of the country, but face legal uncertainty because they are not eligible for hukou registration that is essential to consume government services like education and health care. In this case, a Weberian bureaucracy that would serve this floating population would be really useful! This population counted over 60 million in the late-1990s (Cai, Park, \& Zhao, 2008: p. 35), and almost 79 million in 2000 (Liang \& Ma, 2004). The part of the floating population that does receive work as migrant workers received about $30 \%$ less in wages than urban workers in 2005. The inequality between migrant and urban workers in terms of total compensation is even more pronounced than in terms of wages, because bonuses and insurance contributions are more limited among migrant workers than urban workers (Lee, 2012: p. 465). As of 2009, the average migrant worker also works more hours per week (58.5) than the average urban worker (45) (Rush, 2011). The state-enforced household registration system, the hukou, is institutionalizing discrimination (Liu, 2005; Zhang, 2010), but the capitalists seem to be very content with it.

In the current stage of Chinese capitalism, the cities need to expand further into more remote regions, and developers and investors seeing the profit potential will use the help of the government to capture those areas that are still inhabited by those farmers, who do not voluntarily leave their village despite all the pull-and-push factors toward urban wage labor. It is hard to find evidence for a grand conspiracy behind this policy of land expropriation. But as I see it, there is no inherent necessity for concocting a larger rationale, i.e. the forceful creation of wage labor for sustained capitalist development, which ought to be consciously held by greedy local Communist party officials, and greedy investors and developers. ${ }^{18}$ Even if the expropriation of farmers and their subsequent proletarianization was not intended by the political elites, it would still be an unintended outcome with an unintended boom for continued Chinese capitalism. Capitalism is a complex system, and many parts are moving in a certain direction at different speed. The goal of the historical sociologist is not just to look at the intentions of the social actors, but the larger institutional framework at a given historical moment that produce certain outcomes. During the height of Mao's Communist regime, no one talked about taking away farmers' land so a few officials and developers can make money from it. One might consider this land expropriation in Merton's (1957: pp. 60-69) terms: the manifest function is to clear the land for urban/capital expansion into the countryside, and the latent function is the creation of wage labor- itself a prerequisite for continuing capitalism.

Considering current demographic trends, the pursuit of more wage labor is no idle objective. As the population is aging, and fewer children are born thanks to the one-child policy, there will be an enhanced need for more workers on the labor market (Cai \& Fang, 2006). China's fertility rate decreased from 6 children-per-woman in 1950-55 to 2 in 1990-95, and has dipped below 2 ever since. Life expectancy sharply increased from 40 years in 1950 to 73 in 2009 (Banister, Bloom, \& Rosenberg, 2012: pp. 121-122). The ratio of working-age to nonworking-age population is reaching its peak, and is predicted to decline in a few years (ibid.: p. 123). There is absolutely no doubt that capitalists are forced to consider alternatives to the cheap-labor model, which is discussed in the next paragraph.

The process of land appropriation and proletarianization of the population is in material terms perhaps not as dire as the original appropriation in the fifteenth and sixteenth century Britain. This is because material wealth

\footnotetext{
${ }^{18}$ The psychological ascription "greedy" was added by me, though no Marxist would make those ascriptions.

${ }^{19}$ In addition, China has recorded greater growth in short periods of time than any other country hitherto. Between 1991 and 1996 GDP growth was $12 \%$ per annum, and $8 \%$ - $10 \%$ per annum until 2008, and a after a quick recovery growth resumes at about $8 \%$ (Mann, 2012b: p. 235).
} 
with the current state of technology is certainly greater than previously ${ }^{19}$, and so long as the rising tide lifts all (or most) boats in China, the social discontent will remain limited in that sphere. It is rather unlikely that land expropriation will yield in large, sustainable protests by farmers against Chinese capitalists, in part because farmers are not as naturally well organized as a class (Marx' (1852) famous "sack of potatoes”). Besides, even if they were organized, the agricultural population is shrinking as the urban proletariat is increasing. A large share of people below the age of 40 are already working off the farm, while the remaining agricultural workers are old people (Li et al., 2013). The exciting arena for social conflict in China remains the factory, where wage labor is fighting against company managers to gain wage increases that they deserve due to their labor. The number of so-called mass-incidents, involving strike, protest and riots, increased from 9000 in 1994 to 127,000 in 2008 (Elfstrom \& Kuruvilla, 2012: pp. 3-4). And the Chinese do have a long history of industrial action and activism (e.g. Perry, 1993, 1994; Perry \& Xun, 1997; Frazier, 2002; Solinger, 2009). Ironically, it is in China, where wages are going up by $10 \%-12 \%$ annually, while wages stagnate, and in some cases fall, in the West. The age-induced labor shortage is certainly one key driver of upward wage pressure ( $\mathrm{Li}$ et al., 2013), though there is an enormous wage gap between skill-intensive and labor-intensive workers (Yang, Chen, \& Monarch, 2010).

Chinese capitalists will have to be creative if they want to defend their profits. They will likely plan to shift more investments into more remote areas of the country, which will accelerate the farmer expropriations, or into other countries, where wages and working conditions are not so well regulated. The increase in Made in Vietnam, or Made in Indonesia labels in western supermarkets might be an indication of this process. Wallerstein (2013) argued that it takes 30 years for labor movements in developing countries to form unions, and raise wages sufficiently so that the country no longer is a cheap-labor country. Alternatively, automation is promoted wherever possible. When some Foxconn workers committed suicide, it made so much troublesome headlines across the world that the company management announced to replace these workers with one million machines (Economist, 2011). ${ }^{20}$ Chinese capitalism will have to adapt to a new political economic environment anyway, because the continuing economic growth challenge in the western developed world implies that Chinese export earnings are shrinking, and more economic growth needs to be generated domestically. Furthermore, the investment-driven boom over the last five years since the crisis began is becoming a decreasingly profitable endeavor as overcapacity and overproduction, and speculative asset bubbles loom large. The creation of a social safety net in China, which provides more substantial economic security to the landless peasants and urban migrants in particular, is increasingly becoming an essential goal to accomplish the re-balancing toward more consumer- and internally-driven economic growth, and less income inequality (Lardy \& Borst, 2013). ${ }^{21}$

\section{Conclusion}

The expropriation of rural farmers in contemporary China is an ongoing process, and is embedded within the context of capitalist development in China. Increasing marketization, commoditization, privatization of companies and public services (i.e. the removal of the "iron rice bowl") are the specific institutional context in which Chinese rural transformation is occurring. Marx had theorized that an important pre-requisite to furthering the development of capitalism is the creation of a class of wage laborers through the forceful removal of farmers and other small-scale independent producers via application of state power. David Harvey expanded the concept of primitive accumulation by including measures like privatization or cuts in social services as less-obvious coercive mechanisms to create wage labor. Weber had theorized about the primacy of the state as legitimate actor and agent of violence. Whether it was capitalist reform in the form of the privatization of SOEs, the dismantling of the social welfare system, or the expropriation of the farmers, the state has played a crucial role throughout, and particularly in China, where there is a greater emphasis on central, authoritarian control than in the Western countries (also cf. Appendix).

In any case, contemporary social and economic developments in China are an ideal venue for deploying the theories in conflict sociology. Social conflict remains alive and well in the twenty-first century. In Collins' (1994: p. 112) words, "If we ever felt like rising above our own social conflicts and merely contemplating the science of

\footnotetext{
${ }^{20}$ The most interesting literature on automation and jobs comes from Aronowitz and DiFazio (1994); Rifkin (1995); Collins (2010, 2013); Brynjolfsson and McAfee (2012); Lanier (2013). I myself had written on this issue as well (Liu, 2013b).

${ }^{21}$ Income inequality matters for the re-balancing of the economy insofar as the rich save most of their income (while the bottom $55 \%$ are too poor to save anything), which depresses consumption.
} 
how society operates, the conflict tradition would have to be a central part of that vision.”

\section{References}

Aronowitz, S., \& DiFazio, W. (1994). The Jobless Future: Sci-Tech and the Dogma of Work. Minneapolis: University of Minnesota Press.

Banister, J., Bloom, D. E., \& Rosenberg, L. (2012). Population Aging and Economic Growth in China. In M. Aoki, \& J. L. Wu (Eds.), The Chinese Economy: A New Transition (pp. 114-149). Hampshire: Palgrave Macmillan.

Birnbaum, N. (1953). Conflicting Interpretations of the Rise of Capitalism: Marx and Weber. The British Journal of Sociology, 4, 125-141. http://dx.doi.org/10.2307/587207

Bittman, M. (1986). A Bourgeois Marx? Max Weber’s Theory of Capitalist Society: Reflections on Utility, Rationality and Class Formation. Thesis Eleven, 15, 81-91.

Blumenthal, D., \& Hsiao, W. (2005). Privatization and Its Discontents-The Evolving Chinese Health Care System. New England Journal of Medicine, 353, 1165-1170. http://dx.doi.org/10.1056/NEJMhpr051133

Bourdieu, P. (1998). The State Nobility: Elite Schools in the Field of Power. Stanford, CA: Stanford University Press.

Brandt, L., \& Rawski, T. G. (Eds.) (2008). China's Great Economic Transformation. New York: Cambridge University Press. http://dx.doi.org/10.1017/CBO9780511754234

http://kczx.xhu.edu.cn/G2S/eWebEditor/uploadfile/20120427135908_684449439144.pdf\#page=25

Breslin, S. (2007). China and the Global Political Economy. Basingstoke: Palgrave Macmillan. http://www.untag-smd.ac.id/files/Perpustakaan_Digital_2/POLITICAL\%20ECONOMY\%20China\%20and\%20the\%20glo bal\%20political\%20economy.pdf http://dx.doi.org/10.1057/9780230223943

Brynjolfsson, E., \& McAfee, A. (2012). Race against Machine: How the Digital Revolution Is Accelerating Innovation, Driving Productivity, and Irreversibly Transforming Employment and the Economy. Lexington: Digital Frontier Press.

Cai, F., \& Wang, M. Y. (2006). Challenge Facing China’s Economic Growth in Its Aging but Not Affluent Era. China \& World Economy, 14, 20-31. http://dx.doi.org/10.1111/j.1749-124X.2006.00035.X

Cai, F., Park, A., \& Zhao, Y. H. (2008). Chinese Labor Market in the Reform Era. In L. Brandt, \& T. Rawski (Eds.), China’s Great Economic Transformation (pp. 167-214). New York: Cambridge University Press.

http://iple.cass.cn/upload/2012/06/d20120606093826741.pdf http://dx.doi.org/10.1017/CBO9780511754234.007

Cai, M. (2012). Land-Locked Development: The Local Political Economy of Institutional Change in China. Ph.D. Dissertation, Madison, WI: University of Wisconsin-Madison.

Cai, Y. S. (2003). Collective Ownership or Cadres’ Ownership? The Non-Agricultural Use of Farmland in China. The China Quarterly, 175, 662-680. http://dx.doi.org/10.1017/S0305741003000890

Cai, Y. S. (2008). Local Governments and the Suppression of Popular Resistance in China. The China Quarterly, 193, 24-42.

Campbell, J. L., \& Pedersen, O. K. (Eds.) (2001). The Rise of Neoliberalism and Institutional Analysis. Princeton, NJ: Princeton University Press.

Chambers, J. D. (1953). Enclosure and Labour Supply in the Industrial Revolution. The Economic History Review, 5, 319343. http://dx.doi.org/10.2307/2591811

Chan, A., \& Siu, K. (2012). Chinese Migrant Workers: Factors Constraining the Emergence of Class Consciousness. In B. Carrillo, \& D. S. G. Goodman (Eds.), China's Peasants and Workers: Changing Class Identities (pp. 79-101). Glos: Edward Elgar Publishing. http://dx.doi.org/10.4337/9781781005736.00012

Chan, K. W., \& Hu, Y. (2003). Urbanization in China in the 1990s: New Definition, Different Series, and Revised Trends. China Review, 3, 49-71. http://courses.washington.edu/chinageo/Chan-Hu-urbanization.pdf

Chan, K. W., \& Zhang, L. (1999). The Hukou System and Rural-Urban Migration in China: Processes and Changes. The China Quarterly, 160, 818-855. http://dx.doi.org/10.1017/S0305741000001351

Chang, G. H., \& Brada, J. C. (2006). The Paradox of China’s Growing Under-Urbanization. Economic Systems, 30, 24-40. http://dx.doi.org/10.1016/j.ecosys.2005.07.002

Chen, S. H., \& Ravillion, M. (2008). China Is Poorer than We Thought, but No Less Successful in the Fight against Poverty. Policy Research Working Paper No. 4621, World Bank.

Cheng, X. Q., \& Degryse, H. (2010). The Impact of Bank and Non-Bank Financial Institutions on Local Economic Growth in China. Journal of Financial Services Research, 37, 179-199. http://dx.doi.org/10.1007/s10693-009-0077-4 
Collins, R. (1975). Conflict Sociology: Toward an Explanatory Science. New York: Academic Press.

Collins, R. (1980). Weber's Last Theory of Capitalism: A Systematization. American Sociological Review, 45, 925-942. http://dx.doi.org/10.2307/2094910

Collins, R. (1986). Weberian Sociological Theory. Cambridge: Cambridge University Press. http://dx.doi.org/10.1017/CBO9780511557682

Collins, R. (1994). Four Sociological Traditions. New York: Oxford University Press.

Collins, R. (2010). Technological Displacement and Capitalist Crises: Escapes and Dead Ends. Political Conceptology, 1, 23-34. http://politconcept.sfedu.ru/2010.1/05.pdf

Collins, R. (2013). The End of Middle-Class Work: No More Escapes. In G. Derleugian (Ed.), Does Capitalism Have a Future (pp. 37-70)? New York: Oxford University Press.

Confucius (n.d.). The Analects of Confucius. http://wengu.tartarie.com/wg/wengu.php?l=Lunyu\&no=312

Dahrendorf, R. (1959). Class and Class Conflict in Industrial Society. Stanford, CA: Stanford University Press.

Derleugian, G., Wallerstein, I., Collins, R., Mann, M., \& Calhoun, C. (2013). Does Capitalism Have a Future? New York: Oxford University Press.

Diamond, J. M. (1997). Guns, Germs, and Steel: The Fates of Human Societies. New York: W.W. Norton.

Ding, C. R. (2007). Policy and Praxis of Land Acquisition in China. Land Use Policy, 24, 1-13. http://dx.doi.org/10.1016/j.landusepol.2005.09.002

Ding, D. Z., Goodall, K., \& Warner, M. (2000). The End of the "Iron Rice-Bowl”: Whither Chinese Human Resource Management. International Journal of Human Resource Management, 11, 217-236. http://dx.doi.org/10.1080/095851900339837

Domhoff, G. W. (1990). The Power Elite and the State: How Policy Is Made in America. Poscataway, NJ: Transaction Books.

Du, Y., Park, A., \& Wang, S. G. (2005). Migration and Rural Poverty in China. Journal of Comparative Economics, 33, 688709. http://dx.doi.org/10.1016/j.jce.2005.09.001

Duménil, G., \& Lévy, D. (2001). Costs and Benefits of Neoliberalism. A Class Analysis. Review of International Political Economy, 8, 578-607. http://dx.doi.org/10.1080/09692290110077593

Duménil, G., \& Lévy, D. (2009). The Nature and Contradictions of Neoliberalism. Socialist Register, 38, 43-71.

Duménil, G., \& Lévy, D. (2011). The Crisis of Neoliberalism. Cambridge, MA: Harvard University Press.

Economist (2011). Robots Don’t Complain. August 6, 2011. http://www.economist.com/node/21525432

Elfstrom, M., \& Kuruvilla, S. (2012). The Changing Nature of Labor Unrest in China. Proceedings of the International Labor and Employment Relations Conference, Philadelphia, 2-5 July 2012, 1-44.

http://ilera2012.wharton.upenn.edu/NonRefereedPapers/Kuruvilla,\%20Sarosh\%20and\%20Elfstrom,\%20Manfred.pdf

Elvin, M. (1973). The Pattern of the Chinese Past: A Social and Economic Interpretation. Stanford, CA: Stanford University Press.

Engels, F. (1884). Origins of the Family, Private Property and the State. Marxists.org. http://www.marxists.org/archive/marx/works/1884/origin-family/

Epstein, G. A. (Ed.) (2005). Financialization and the World Economy. Cheltenham, UK: Edward Elgar Publishing.

Frazier, M. W. (2002). The Making of the Chinese Industrial Working Place: State, Revolution and Labor Management. New York: Cambridge University Press. http://dx.doi.org/10.1017/CBO9780511510076

Fung, H. L. (2001). The Making and Melting of the "Iron Rice Bowl” in China 1949 to 1995. Social Policy \& Administration, 35, 258-273. http://dx.doi.org/10.1111/1467-9515.00232

Gates, H. (1987). Money for the Gods. Modern China, 13, 259-277. http://dx.doi.org/10.1177/009770048701300301

Giddens, A. (1970). Marx, Weber, and the Development of Capitalism. Sociology, 4, 289-310. http://dx.doi.org/10.1177/003803857000400301

Giles, J., Park, A., \& Zhang, J. W. (2005). What Is China’s True Unemployment Rate? China Economic Review, 16, $149-170$. http://dx.doi.org/10.1016/j.chieco.2004.11.002

Gobel, C., \& Ong, L. (2012). Social Unrest in China. London: Europe China Research and Advice Network. http://www.euecran.eu/Long\%20Papers/ECRAN\%20Social\%20Unrest\%20in\%20China_\%20Christian\%20Gobel\%20and \%20Lynette\%20H.\%20Ong.pdf

Goldstone, J. A. (1991). Revolution and Rebellion in the Early Modern World. Berkeley and Los Angeles, CA: University of California Press. 
Graham, E. M., \& Wada, E. (2003). Foreign Direct Investment in China, In: P. Drysdale, Y. Huang, \& M. Kawai (Eds.), Achieving High Growth: Experience of Transitional Economies in East Asia (pp. 112-134). London and Sydney: Routledge.

Granovetter, M. (1985). Economic Action and Social Structure: The Problem of Embeddedness. American Journal of Sociology, 91, 481-510. http://sociology.stanford.edu/people/documents/Embeddedness1985AJS.pdf http://dx.doi.org/10.1086/228311

Guo, X. (2001). Land Expropriation and Rural Conflicts in China. The China Quarterly, 166, 422-439. http://links.jstor.org/sici?sici=0305-7410\%28200106\%290\%3A166\%3C422\%3ALEARCI\%3E2.0.CO\%3B2-T

Habermas, J. (1975). Legitimation Crisis. Boston, MA: Beacon Press.

Hare, D. (1999). "Push” versus "Pull” Factors in Migration Outflows and Returns: Determinants of Migration Status and Spell Duration among China’s Rural Population. The Journal of Development Studies, 35, 45-72. http://dx.doi.org/10.1080/00220389908422573

Harrell, S. (1987). The Concept of Fate in Chinese Folk Ideology. Modern China, 13, 90-109. http://dx.doi.org/10.1177/009770048701300105

Harvey, D. (2003). The New Imperialism. Oxford: Oxford University Press. http://eatonak.org/IPE501/downloads/files/New\%20Imperialism.pdf

Harvey, D. (2005). A Brief History of Neoliberalism. New York: Oxford University Press. http://www.sok.bz/web/media/video/ABriefHistoryNeoliberalism.pdf

Harvey, D. (2010). The Enigma of Capital and the Crises of Capitalism. New York: Oxford University Press.

Hasan, I., Wachtel, P., \& Zhou, M. M. (2009). Institutional Development, Financial Deepening and Economic Growth: Evidence from China. Journal of Banking \& Finance, 33, 157-170. http://dx.doi.org/10.1016/j.jbankfin.2007.11.016

He, S. J., Liu, Y. T., Webster, C., \& Wu, F. L. (2009). Property Rights Redistribution, Entitlement Failure and the Impoverishment of Landless Farmers in China. Urban Studies, 46, 1925-1949. http://dx.doi.org/10.1177/0042098009106015

He, X. H. (2009). The Development of Entrepreneurship and Private Enterprise in the People's Republic of China and Its Relevance to Transitional Economies. Journal of Developmental Entrepreneurship, 14, 39-58. http://dx.doi.org/10.1142/S1084946709001132

Hilferding, R. (1910). Finance Capital (Finanzkapital). Marxists.org. https://www.marxists.org/archive/hilferding/1910/finkap/index.htm

Hill, C. (1972). The World Turned Upside Down: Radical Ideas During the English Revolution. London: Temple Smith.

Hobbes, T. (1969). Leviathan. Aldershot: Scolar Press.

Hu, A. G. (2007). Economic and Social Transformation in China. Oxon: Routledge.

Huang, Y. S. (2008). Capitalism with Chinese Characteristics. New York: Cambridge University Press. http://www.langtoninfo.com/web_content/9780521898102_frontmatter.pdf http://dx.doi.org/10.1017/CBO9780511754210

Hughes, N. C. (1998). Smashing the Iron Rice Bowl. Foreign Affairs, 77, 67-77. http://dx.doi.org/10.2307/20048966

Khan, A. R., \& Riskin, C. (1998). Income and Inequality in China: Composition, Distribution and Growth of Household Income, 1988 to 1995. The China Quarterly, 154, 221-253. http://dx.doi.org/10.1017/S0305741000002022

Knight, J., \& Song, L. N. (1999). The Rural-Urban Divide: Economic Disparities and Interactions in China. Oxford: Oxford University Press. http://dx.doi.org/10.1093/acprof:oso/9780198293309.001.0001

Knight, J., Song, L. N., \& Jia, H. B. (1999). Chinese Rural Migrants in Urban Enterprises: Three Perspectives. Journal of Development Studies, 35, 73-104. http://dx.doi.org/10.1080/00220389908422574

Kraus, W. (1991). Private Business in China: Revival between Ideology and Pragmatism. Honolulu, HI: University of Hawaii Press.

Krippner, G. R. (2005). The Financialization of the American Economy. Socio-Economic Review, 3, 173-208. http://dx.doi.org/10.1093/SER/mwi008

Lanier, J. (2013). Who Owns the Future? New York: Simon and Schuster.

Lardy, N. R. (2002). Integrating China into the Global Economy. Washington DC: Brookings Institution Press.

Lardy, N., \& Borst, N. (2013). A Blueprint for Rebalancing the Chinese Economy. Peterson Institute for International Economics, Policy Brief, No. 13-02. http://spaces.iie.com/publications/pb/pb13-2.pdf

Lee, L. (2012). Decomposing Wage Differentials between Migrant Workers and Urban Workers in Urban China's Labor Markets. China Economic Review, 23, 461-470. http://dx.doi.org/10.1016/j.chieco.2012.03.004 
Lenin, V. I. (1917). Imperialism: The Highest Stage of Capitalism (Империализмкаквысшаястадиякапитализма). Marxists.org. http://www.marxists.org/archive/lenin/works/1916/imp-hsc/

Lenski, G. E. (1966). Power and Privilege: A Theory of Social Stratification. Chapel Hill, NC: University of North Carolina Press.

Leung, J. C. B. (1994). Dismantling the "Iron Rice Bowl”: Welfare Reforms in the People’s Republic of China. Journal of Social Policy, 23, 341-361. http://dx.doi.org/10.1017/S0047279400021899

Li, Q., Huang, J. K., Luo, R. F., \& Liu, C. F. (2013). China’s Labor Transition and the Future of China’s Rural Wages and Employment. China \& World Economy, 21, 4-24. http://dx.doi.org/10.1111/j.1749-124X.2013.12019.x

Liang, Z., \& Ma, Z. D. (2004). China’s Floating Population: New Evidence from the 2000 Census. Population and Development Review, 30, 467-488. http://dx.doi.org/10.1111/j.1728-4457.2004.00024.x

Lichtenberg, E., \& Ding, C. R. (2008). Assessing Farmland Protection Policy in China. Land Use Policy, 25, 59-68. http://dx.doi.org/10.1016/j.landusepol.2006.01.005

Lin, J. Y., Cai, F., \& Li, Z. (1996). The China Miracle: Development Strategy and Economic Reform. Hong Kong: Chinese University Press. http://www.cato.org/sites/cato.org/files/serials/files/cato-journal/1998/1/cj18n1-11.pdf

Liu, L. (2013a). Does Marx Still Matter in the 21st Century? Mr. Liu’s Opinion, October 11.

Liu, L. (2013b). Technology and Unemployment: The Future of the Labor Market and Jobs. Penn Political Review, November 11 .

http://pennpoliticalreview.org/2013/11/technology-and-unemployment-the-future-of-the-labor-market-and-jobs/

Liu, S. H., Li, X. B., \& Zhang, M. (2003). Scenario Analysis on Urbanization and Rural-Urban Migration in China. Vienna: International Institute for Applied Systems Analysis.

http://webarchive.iiasa.ac.at/Admin/PUB/Documents/IR-03-036.pdf

Liu, W. D., \& Lou, L. M. (2004). A Review on the Land Expropriation and Its Management in China. Journal of Zhejiang University, 1, 63-68.

Liu, Z. Q. (2005). Institution and Inequality: The Hukou System in China. Journal of Comparative Economics, 33, $133-157$. http://dx.doi.org/10.1016/j.jce.2004.11.001

Lu, C. Z. (2012). Poverty and Development in China: Alternative Approaches to Poverty Assessment. London: Routledge.

Lu, X. B. (2000). Booty Socialism, Bureau-Preneurs, and the State in Transition: Organizational Corruption in China. Comparative Politics, 32, 273-294. http://dx.doi.org/10.2307/422367

https://webspace.utexas.edu/hl4958/contemporary-chinese-history/Lu\%20-\%20Organizational\%20Corruption\%20in\%20C hina.pdf

Luxemburg, R. (1913). The Accumulation of Capital. Marxists.org. http://www.marxists.org/archive/luxemburg/1913/accumulation-capital/

Ma, T. P., Fok, H. Y., \& Ko, W. S. (1997). China’s Public Policies under Reform. Beijing: Chinese Economic Publisher.

Mann, M. (1986). The Sources of Social Power, Vol. I: A History of Power from the Beginning to 1760 AD. Cambridge: Cambridge University Press. http://dx.doi.org/10.1017/CBO9780511570896

Mann, M. (1993). The Sources of Social Power: Vol. 2, The Rise of Classes and Nation States 1760-1914. Cambridge: Cambridge University Press. http://dx.doi.org/10.1017/CBO9780511570902

Mann, M. (2012a). The Sources of Social Power: Vol. 3, Global Empires and Revolution, 1890-1945. Cambridge: Cambridge University Press.

Mann, M. (2012b). The Sources of Social Power: Vol. 4, Globalizations, 1945-2011. Cambridge: Cambridge University Press.

Mannheim, K. (1940). Man and Society in an Age of Reconstruction: Studies in Modern Social Structure. London: Routledge \& Kegen Paul.

Marx, K. (1846). The German Ideology. Marxists.org. http://www.marxists.org/archive/marx/works/1845/german-ideology/

Marx, K. (1848). Manifesto of the Communist Party. Marxists.org. http://www.marxists.org/archive/marx/works/1848/communist-manifesto/

Marx, K. (1850). Class Struggles in France. Marxists.org. http://www.marxists.org/archive/marx/works/1850/class-struggles-france/index.htm

Marx, K. (1852). The Eighteenth Brumaire of Louis Bonaparte. Marxists.org. http://www.marxists.org/archive/marx/works/1852/18th-brumaire/

Marx, K. (1867). Capital Vol. 1. Marxists.org. http://www.marxists.org/archive/marx/works/1867-c1/

Marx, K. (1871). The Civil War in France. Marxists.org. http://www.marxists.org/archive/marx/works/1871/civil-war-france/index.htm 
Marx, K. (1875). Critique of the Gotha Program. Marxists.org.

http://www.marxists.org/archive/marx/works/1875/gotha/index.htm

Marx, K. (1885). Capital Vol. 2. Marxists.org. http://www.marxists.org/archive/marx/works/1885-c2/

Marx, K. (1894). Capital Vol. 3. Marxists.org. http://www.marxists.org/archive/marx/works/1894-c3/

Mencius (n.d.) The Works of Mencius. http://nothingistic.org/library/mencius/mencius07.html

Merton, R. K. (1957). Social Theory and Social Structure. Glencoe, IL: Free Press.

Meyer, M. W. (2011). Is It Capitalism? Management and Organization Review, 7, 5-18.

http://dx.doi.org/10.1111/j.1740-8784.2011.00211.x

Mills, C. W. (1956). The Power Elite. Oxford: Oxford University Press.

Moore Jr., B. (1967). Social Origins of Dictatorship and Democracy. Boston, MA: Beacon Press.

Naughton, B. (1995). Growing out of the Plan: Chinese Economic Reform, 1978-1993. New York: Cambridge University Press. http://dx.doi.org/10.1017/CBO9780511664335

Naughton, B. (2007). The Chinese Economy: Transitions and Growth. Cambridge, MA: MIT Press.

Nee, V. (1991). Social Inequalities in Reforming State Socialism: Between Redistribution and Markets in China. American Sociological Review, 56, 267-282. http://dx.doi.org/10.2307/2096103

http://www.soc.cornell.edu/faculty/nee/pubs/socialinequalitiesinreformingstatesocialism.pdf

Nee, V., \& Opper, S. (2012). Capitalism from Below: Markets and Institutional Change in China. Cambridge, MA: Harvard University Press. http://dx.doi.org/10.4159/harvard.9780674065390

Nuyen, A. T. (2013). The "Mandate of Heaven": Mencius and the Divine Command Theory of Political Legitimacy. Philosophy East and West, 63, 113-126. http://dx.doi.org/10.1353/pew.2013.0014

Oi, J. C. (1995). The Role of the Local State in China’s Transitional Economy. China Quarterly, 144, 1132-1150. http://dx.doi.org/10.1017/S0305741000004768

Oxfeld, E. (1993). Blood, Sweat, and Mahjong: Family and Enterprise in an Overseas Chinese Community. Ithaca, NY: Cornell University Press.

Paden, R. (2002). Marx’s Critique of the Utopian Socialists. Utopian Studies, 13, 67-91.

Parsons, T. (1937). The Structure of Social Action. Whitby, ON: McGraw-Hill.

Perry, E. J. (1993). Shanghai on Strike: The Politics of Chinese Labor. Stanford, CA: Stanford University Press.

Perry, E. J. (1994). Shanghai’s Strike Wave of 1957. China Quarterly, 137, 1-27. http://dx.doi.org/10.1017/S0305741000034020

Perry, E. J., \& Li, X. (1997). Proletarian Power: Shanghai in the Cultural Revolution. Boulder, CO: Westview Press.

Polanyi, K. (1944). The Great Transformation: Economic and Political Origins of Our Time. New York: Rinehart.

Rifkin, J. (1995). The End of Work: The Decline of the Global Labor Force and the Dawn of the Post-Market Era. New York: Putnam.

Rural Investigation Team, China Statistical Bureau (2003). Shidinongmin de kunnan, xintai he xuyaojiejue de wenti (The Difficulty, Thoughts and Unsolved Problems of Landless Farmers). http://www.sannong.gov.cn.

Rush, A. (2011). China’s Labour Market. Reserve Bank of Australia. http://www.rba.gov.au/publications/bulletin/2011/sep/4.html

Schumpeter, J. A. (1942). Socialism, Capitalism and Democracy. New York: Harper and Brothers.

Seeborg, M. C., Jin, Z. H., \& Zhu, Y. P. (2000). The New Rural-Urban Labor Mobility in China: Causes and Implications. Journal of Socio-Economics, 29, 39-56. http://dx.doi.org/10.1016/S1053-5357(00)00052-4

Shi, Y. Z. (2001). Technological Capabilities and International Production Strategy of Firms: The Case of Foreign Direct Investment in China. Journal of World Business, 36, 184-204. http://dx.doi.org/10.1016/S1090-9516(01)00048-7

Skocpol, T. (1979). States and Social Revolutions. Cambridge: Cambridge University Press. http://dx.doi.org/10.1017/CBO9780511815805

Solinger, D. (2009). State’s Gains, Labor's Losses: China, France, and Mexico Choose Global Liaisons, 1980-2000. Ithaca: Cornell University Press.

Song, S. F., \& Zhang, K. H. (2002). Urbanisation and City Size Distribution in China. Urban Studies, 39, $2317-2327$. http://dx.doi.org/10.1080/0042098022000033890

Stockhammer, E. (2010). Neoliberalism, Income Distribution and the Causes of the Crisis. Research on Money and Finance, London. 
Streeck, W. (2013). The Politics of Public Debt: Neoliberalism, Capitalist Development, and the Restructuring of the State. Max Planck-Institut fur Gesellschaftsforschung, Discussion Paper 13/7. http://www.mpifg.de/pu/mpifg_dp/dp13-7.pdf

Sweezy, P. M. (1942). Theory of Capitalist Development. New York: Monthly Review Press.

Taylor, J. (2009). The Generalissimo: Chiang Kai-shek and the Struggle for Modern China. Cambridge, MA: Harvard University Press.

Teiwes, F. C., \& Sun, W. (1999). China's Road to Disaster: Mao, Central Politicians, and Provincial Leaders in the Unfolding of the Great Leap Forward, 1955-1959. New York: ME Sharpe.

Tucker, R. C. (Ed.) (1978). The Marx-Engels Reader. New York: W.W. Norton. http://leftygazette.files.wordpress.com/2012/01/karl-marx-friedrich-engels-the-marx-engels-reader.pdf

Useem, M. (1979). The Social Organization of the American Business Elite and Participation of Corporation Directors in the Governance of American Institutions. American Sociological Review, 44, 553-572. http://dx.doi.org/10.2307/2094587

Wakefield, E. G. (1833). England and America, Volume 1. London: R. Bentley.

Walder, A. G. (1989). Factory and Manager in an Era of Reform. China Quarterly, 118, 242-264. http://dx.doi.org/10.1017/S030574100001780X

Walder, A. G. (1995). Local Government as Industrial Firms: An Organizational Analysis of China’s Transitional Economy. American Journal of Sociology, 101, 263-301. http://dx.doi.org/10.1086/230725

Wallerstein, I. (1974). The Modern World-System, I: Capitalist Agriculture and the Origins of the European World-Economy in the Sixteenth Century. San Diego, CA: Academic Press.

Wallerstein, I. (1980). The Modern World-System, II: Mercantilism and the Consolidation of the European World-Economy, 1600-1750. New York: Academic Press.

Wallerstein, I. (1989). The Modern World-System, Vol. III: The Second Great Expansion of the Capitalist World-Economy, 1730-1840's. San Diego, CA: Academic Press.

Wallerstein, I. (2011). The Modern World-System, Vol. IV: Centrist Liberalism Triumphant, 1789-1914. Berkeley, CA: University of California Press.

Wallerstein, I. (2013). Structural Crisis, or Why Capitalists May No Longer Find Capitalism Rewarding. In G. Derleugian (Ed.), Does Capitalism Have a Future (pp. 9-36)? New York: Oxford University Press.

Ward, B. (1980). The Chinese Approach to Economic Development. In R. Dernberger (Ed.), China's Development Experience in Comparative Perspective (pp. 91-119). Cambridge, MA: Harvard University Press. http://dx.doi.org/10.4159/harvard.9780674367388.c5

Webb, D. (2000). Marx, Marxism and Utopia. Aldershot, UK: Ashgate Pub.

Weber, M. (1946). From Max Weber: Essays in Sociology. New York: Oxford University Press.

Weber, M. (1948). The Theory of Social and Economic Organization. New York: Oxford University Press.

Weber, M. (1978). Economy and Society: An Outline of Interpretive Sociology. Berkeley, CA: University of California Press.

Weber, M. (1981). General Economic History. Brunswick: Transaction Books.

Wong, K., Fu, D., Li, C. Y., \& Song, H. X. (2007). Rural Migrant Workers in Urban China: Living a Marginalised Life. International Journal of Social Welfare, 16, 32-40.

Wong, L. (2001). Welfare Policy Reform. In L. Wong, \& N. Flynn (Eds.), The Market in Chinese Social Policy (38-62). Basingstoke: Palgrave. http://dx.doi.org/10.1057/9781403919939

Wright, E. O. (1997). Class Counts: Comparative Studies in Class Analysis. New York: Cambridge University Press. http://www.ssc.wisc.edu/ wright/Published\%20writing/Class-Counts-chapter-1.pdf

Wu, H. X. (1994). Rural to Urban Migration in the People’s Republic of China. China Quarterly, 139, 669-698. http://dx.doi.org/10.1017/S0305741000043095

Wu, H. X., \& Zhou, L. (1996). Rural-to-Urban Migration in China. Asian-Pacific Economic Literature, 10, 54-67. http://dx.doi.org/10.1111/j.1467-8411.1996.tb00016.x

Xue, J. J., \& Zhong, W. (2003). Unemployment, Poverty and Income Disparity. Asian Economic Journal, 17, 383-405. http://dx.doi.org/10.1111/j.1467-8381.2003.00192.x

Yan, S. (2004). Corruption and Market in Contemporary China. Ithaca, NY: Cornell University Press.

Yang, D. L. (2004). Remaking the Chinese Leviathan: Market Transition and the Politics of Governance in China. Stanford, CA: Stanford University Press.

Yang, D. T. (1999). Urban-Biased Policies and Rising Income Inequality in China. American Economic Review, 89, $306-310$. http://dx.doi.org/10.1257/aer.89.2.306

Yang, D. T., Chen, V. W., \& Monarch, R. (2010). Rising Wages: Has China Lost Its Global Labor Advantage? Pacific Economic Review, 15, 482-504. http://dx.doi.org/10.1111/j.1468-0106.2009.00465.x 
Yao, Y., \& Yueh, L. (2009). Law, Finance, and Economic Growth in China: An Introduction. World Development, 37, 753762. http://dx.doi.org/10.1016/j.worlddev.2008.07.009

Yip, B. S. W. (2006). Privatisation. In C. Tubilewicz (Ed.), Critical Issues in Contemporary China (pp. 49-78). Oxon, UK: Routledge.

Zhang, H. F. (2010). The Hukou System's Constraints on Migrant Workers' Job Mobility in Chinese Cities. China Economic Review, 21, 51-64. http://dx.doi.org/10.1016/j.chieco.2009.10.002

Zhang, K. H. (2005). Why Does So Much FDI from Hong Kong and Taiwan Go to Mainland China? China Economic Review, 16, 293-307. http://dx.doi.org/10.1016/j.chieco.2005.02.004

Zhang, K. H., \& Song, S. F. (2003). Rural-Urban Migration and Urbanization in China: Evidence from Time-Series and Cross-Section Analyses. China Economic Review, 14, 386-400. http://dx.doi.org/10.1016/j.chieco.2003.09.018

Zhang, X. H., \& Yuk, H. P. (1998). Determinants of Hong Kong Manufacturing Investment in China: A Survey. Marketing Intelligence \& Planning, 16, 260-267. http://dx.doi.org/10.1108/02634509810224446

Zhao, X. (2006). Analysis of Income Gap between Urban and Rural Residents in our Country. Cooperative Economy and Technology and Sciences, 6, 12-13.

Zhao, Y. H. (1999a). Leaving the Countryside: Rural-to-Urban Migration Decisions in China. The American Economic Review, 89, 281-286. http://dx.doi.org/10.1257/aer.89.2.281

Zhao, Y. H. (1999b). Labor Migration and Earnings Differences: The Case of Rural China. Economic Development and Cultural Change, 47, 767-782. http://dx.doi.org/10.1086/452431

Zhao, Y. J., \& Webster, C. (2011). Land Dispossession and Enrichment in China’s Suburban Villages. Urban Studies, 48, 529-551. http://dx.doi.org/10.1177/0042098010390238

Zweig, D., \& Chen, Z. M. (Eds.) (2007). China’s Reforms and International Political Economy, Volume 27. Oxon: Routledge.

http://www.untag-smd.ac.id/files/Perpustakaan_Digital_2/POLITICAL\%20ECONOMY\%20China\%92s\%20reforms\%20a nd\%20international\%20political\%20economy.pdf 


\section{Appendix - China in Context with the Marxian Historical Scheme}

In the case of China, the researcher is faced with an alteration of the original Marxian historical scheme of feudalism-capitalism-socialism ${ }^{22}$, because in the Chinese case socialism precedes the rise of capitalism. But I don't necessarily see a problem with such alteration, because the real world is complex enough to accommodate for this outcome. As Marx (1852) correctly remarked, history may be in men’s making, but not in its own choosing. Any foregone conclusions about history have to be addressed with a great deal of skepticism. From a world-historical viewpoint, Chinese-style socialism had clearly become unbearable, and the Communist party leadership saw the faltering of the Soviet Union, and the impending doom to socialist regimes across the world. Socialism is nice and okay if it exists on a comprehensive scale, where no capitalist interests could undermine the regime from the outside (Collins, 1994: p. 74). As many Marxists (especially Karl Kautsky, Georg Lukacs, Maurice Meisner and Frederick Jameson) would argue, it is simply impossible to create a successful utopian, socialist society in the context of a dominant bourgeois world order (Paden, 2002: p. 72; Webb, 2000: pp. 5-9). Another way to look at it is that China pre-1949 had a tremendous amount of experience with capitalism and commoditization. The Chinese had treated the major factors of production as commodities, even as capitalist elements were put under tight state control (Gates, 1987: p. 260). Monetization of the Chinese society took off in the eleventh century (Elvin, 1973: p. 149), even within rural areas among the peasantry (ibid.: p. 106). A strong entrepreneurial ethic pervaded China’s culture (Harrell, 1987: p. 94). ${ }^{23}$ From this perspective, Chinese communism can thus be considered more an aberration than a natural tendency. In this context, China's turn from socialism to capitalism becomes more clearly understandable.

The Chinese communist social structure contained some essentially feudalist elements, because the land belonged to the local governments, even as the farmers have supposedly control rights over it. This dependence relationship, which would fit very well with conflict sociologists' understanding of power ${ }^{24}$, is more reminiscent to a dictatorship of the party state rather than the dictatorship of the proletariat, and certainly reminiscent to feudal Europe. Deng Xiaoping himself was a great admirer of Hong Kong's and Singapore’s road to economic success (Leung, 1994: p. 347), which mixed economic liberalization with strong, centralized political control. Interestingly, within the context of Chinese history and political philosophy, there had been a consistent focus on raising strong political leaders, usually in the form of kings, controlling dynasties, rather than let the unruly masses go their own way. As Confucius (n.d.: Book 12, Chapter 9) writes, “The virtue of the gentlemen [leader, king] is like wind; the virtue of the small man is like grass. Let the wind blow over the grass and it is sure to bend." Confucius acted as a scholar in residence, advising the kings, without devoting any thoughts on public participation in politics. (Where would the cultural and economic support for that come from?) Though to be fair, one of Confucius' followers, Mencius (n.d.: Book 1, Chapter 8), refined some of his master's ideas, and argued that while the common people do have to submit to a leader this leader is subjected to the Mandate of Heaven. ${ }^{25}$ This appears to

${ }^{22}$ Actually primitive communism-feudalism-capitalism-socialism-communism. But for the sake of simplicity, the first step can be dropped, and the last two can be merged. Marx and Engels also seemed to be using the terms socialism and communism interchangeably, though one difference appears to be that social is the takeover of the state by the working class, and communism is the highest social stage, when the state has "withered away". In other words, no more social conflict, which is a somewhat vain hope for conflict sociologists.

${ }^{23}$ One example of Chinese entrepreneurship is provided by my own family/ancestors, the Hakka Chinese based in Calcutta, India. They have been well characterized by anthropologist Ellen Oxfeld's (1993) account, where she described the Hakka Chinese in Calcutta as "pariah capitalists" (ibid.: pp. 12-17), because in the late nineteenth and most of the twentieth century, they flourished in running leather tanneries (leather was among the largest materials of export in India), which was considered “dirty” work by the native Indians. (My uncle still runs a tannery, though much smaller than during the heydays in the mid-twentieth century.) The Hakka Chinese had very little sense of cleanliness and cared mainly about the profits that were derived from running leather tanneries and occupying this economic niche. Whereas the native Indians cared about the caste system and propriety of the nature of work, the Chinese cared about status, wealth and business, which the tannery business gave them (ibid.: pp. 94-99). The Chinese' economic success, however, was overshadowed by political-organizational weakness, which mattered during the skirmish between India and China. When the Sino-Indian War broke out in 1962, many Chinese were either deported back to China, sent into the internment camp in the western province of Rajasthan, or had to register every year with the Indian government bureaucracy to continue to stay in Calcutta (ibid.: pp. 80-85), though my own relatives were spared from the first two forms of treatment. This explained the increasing exodus of Hakka Chinese to Toronto, Canada, where almost all of my relatives currently reside in. Interestingly, most of those Chinese in Canada now work as wage laborers in Canadian factories rather than as business owners like they were in India (ibid.: p. 256), even as many Chinese think that "working for other people" is not as good as being their own boss (ibid.: p. 255). The Mar- xian hypothesis of the historical tendency to proletarianize the petty bourgeoisie and small independent producers in vastly different regional contexts holds up well.

${ }^{24}$ Weber (1978: p. 53) defines power as "the probability that one actor within a social relationship will be in a position to carry out his own will despite resistance, regardless of the basis on which this probability rests.” Mann (1986: p. 1) viewed power in ideological, military, economic and political terms.

${ }^{25}$ The passage reads, The king said, "May a minister then put his sovereign to death?” Mencius said, "He who outrages the benevolence proper to his nature is called a robber; he who outrages righteousness, is called a ruffian. The robber and ruffian we call a mere fellow. I have heard of the cutting off the fellow of Zhou, but I have not heard of the putting a sovereign to death, in his case.” (Mencius, n.d.: Book 1, Chapter 8). 
be very abstract, and from a western religious viewpoint may easily be misinterpreted as an arbitrary god making any decision that the ruler stipulates. ${ }^{26}$

But the Mandate of Heaven really involves combined popular opinion. The leaders have to submit to popular opinion, or else they are liable to be kicked out by another leader, who receives Heaven's blessing. This is as close to a representative democracy as one could get ${ }^{27}$ One of the reasons why Chiang Kai-shek's Guomindang proved so unpopular to the masses was that they did virtually nothing to benefit the peasants, which were the majority of the population. The Communists promised land reform, and the Heavenly Mandate (with huge popular and peasant support) wandered over to Mao Zedong. In a more general way, Weber argued that direct democracy is unrealistic anywhere, and had ironically been only possible in aristocratic circles like the aristocracy in Venice and Sparta, or among the German university professors, due to their relatively small number, the relative equality of the members, and their simple and well-trained administration (Weber, 1978: p. 949). Another fitting example would be ancient Athens, whose aristocracy formulated democracy with due exclusion of slaves, minors, women and non-property holders.

\footnotetext{
${ }^{26}$ The British kings and queens regarded themselves as the "deputy" of God. A similar comparison may be made with the Catholic pope.

${ }^{27}$ Though there are scholars, who disagree. Nuyen (2013: p. 113) sees two possible interpretations of the Mandate of Heaven: the liberal, which I described, and the conservative, which argues that the will of heaven "transcends" the common people.
} 
Scientific Research Publishing (SCIRP) is one of the largest Open Access journal publishers. It is currently publishing more than 200 open access, online, peer-reviewed journals covering a wide range of academic disciplines. SCIRP serves the worldwide academic communities and contributes to the progress and application of science with its publication.

Other selected journals from SCIRP are listed as below. Submit your manuscript to us via either submit@scirp.org or Online Submission Portal.
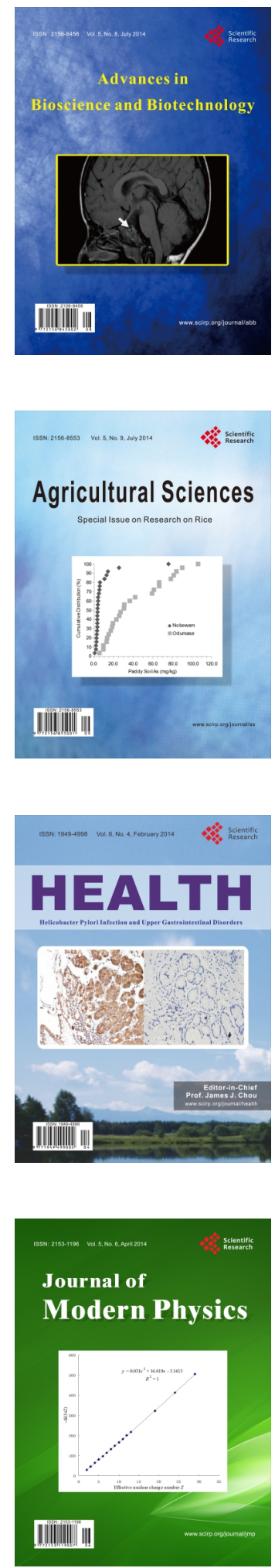
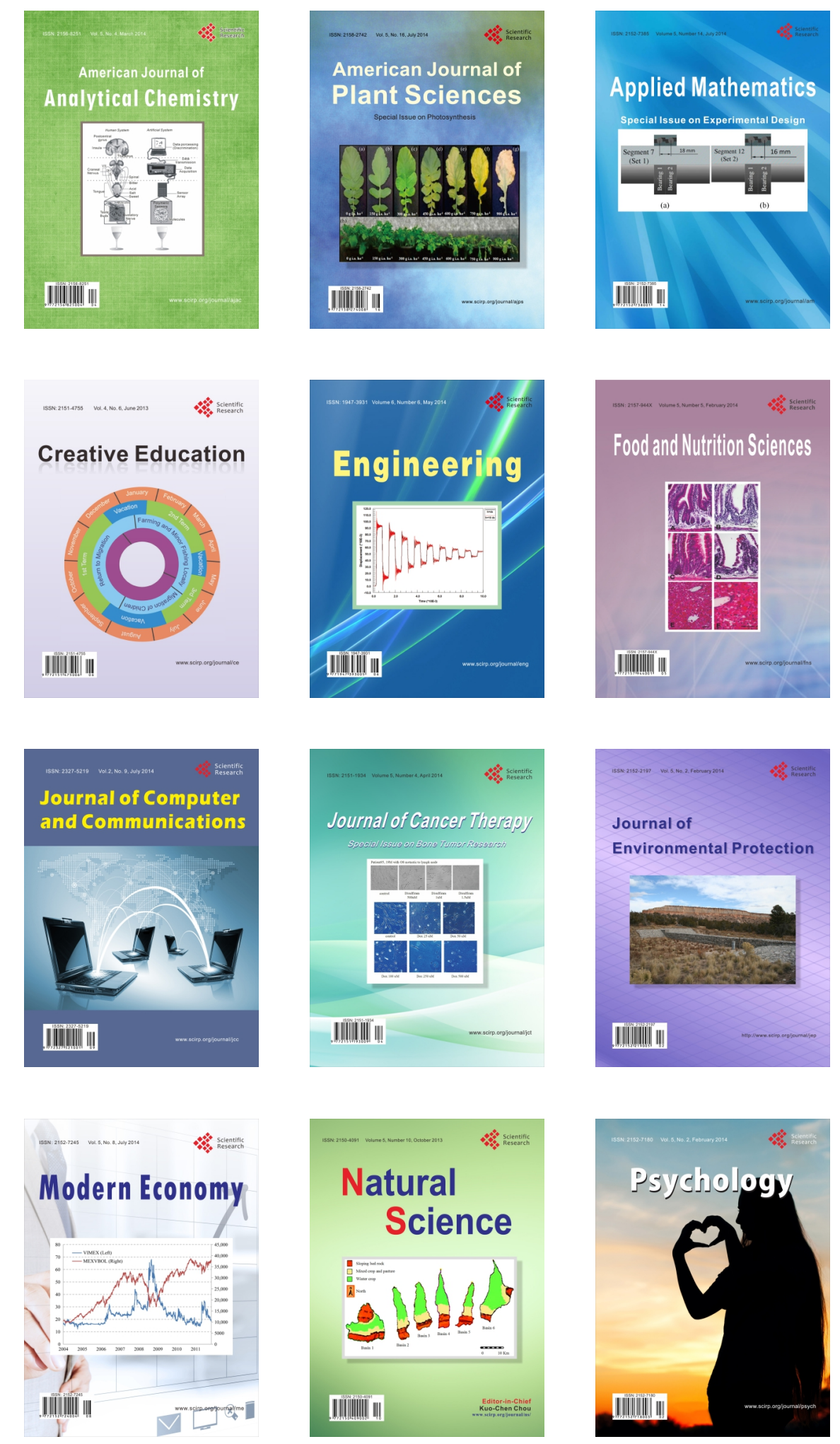